DOI: https://doi.org/10.47405/mjssh.v5i11.562

\begin{tabular}{|c|c|}
\hline 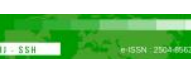 & Malaysian Journal of Social Sciences and Humanities (MJ - SSH) \\
\hline Malaysian Journal of & Volume5, Issue 4, April 2020 \\
\hline (MJ-sSH) & e-ISSN : 2504-8562 \\
\hline & $\begin{array}{l}\text { Journal home page: } \\
\text { www.msocialsciences.com }\end{array}$ \\
\hline
\end{tabular}

\title{
Penjanaan Komposisi Sisa Pepejal terhadap Amalan Kitar Semula di Sekolah Menengah Datuk Peter Mojuntin, Penampang, Sabah
}

\author{
Chong Oi Min¹, Mohammad Tahir Mapa1 \\ ${ }^{1}$ Fakulti Sains Sosial dan Kemanusiaan, Universiti Malaysia Sabah (UMS) \\ Correspondence: Chong Oi Min (oimin3344@gmail.com)
}

\begin{abstract}
Abstrak
Pada masa kini, pertambahan jumlah pelajar sekolah menengah adalah semakin ramai pada setiap tahun. Fenomena ini telah mendatangkan masalah kepada penjanaan komposisi sisa pepejal yang tidak terkawal malah mencemarkan alam sekitar. Penjanaan komposisi sisa pepejal yang banyak merupakan masalah yang cukup rumit untuk diatasi. Oleh itu, satu tinjauan awal berkaitan penjanaan komposisi sisa pepejal dengan menggunakan cara kitar semula telah dijalankan di sebuah sekolah menengah di daerah Penampang. Kajian ini bertujuan untuk mengenal pasti jenis dan jumlah sampah yang dihasilkan oleh semua warga sekolah dalam masa sebulan pada hari persekolahan. Pengkaji telah menggunakan reka bentuk tinjauan dengan mengaplikasikan pendekatan kualitatif iaitu melalui temubual tidak berstruktur dan pemerhatian ikut serta dalam kajian ini. Populasi kajian adalah pelajar tingkatan empat, pekerja pembersih dan pegawai majlis daerah Penampang untuk mengukur dan menimbang jumlah sampah yang dihasilkan dalam sehari dan seminggu dengan menggunakan alat penimbang elektronik. Melalui pengiraan dalam bentuk peratus dan kiraan berat dalam kilogram. Hasil dapatan menunjukkan dengan jelas sisa pepejal terbanyak yang dihasilkan adalah sisa makanan iaitu sebanyak $75.63 \mathrm{~kg}$, kedua banyak adalah plastik $71.46 \mathrm{~kg}$ dan ketiga adalah polisterina sebanyak $61.35 \mathrm{~kg}$ daripada jumlah sisa pepejal dalam masa seminggu. Manakala sebanyak $38 \%$ daripada sisa pepejal yang dihasilkan oleh semua warga sekolah merupakan barangan yang tidak boleh dikitar semula dan sebanyak $34 \%$ merupakan bahan yang berpotensi serta boleh dikitar semula tetapi tidak boleh dijual kepada vendor. Manakala sebanyak $28 \%$ daripada sisa pepejal yang dijana terdiri daripada bahan yang boleh dikitar semula dan boleh dijual kepada vendor. Dengan jumlah komposisi sisa pepejal yang dihasilkan, maka pihak sekolah boleh mengambil langkah kitar semula untuk mengurangkan jumlah sampah yang akan dihasilkan dan dihantar ke tapak pelupusan. Oleh itu, pihak sekolah harus mengadakan pelbagai program kitar semula secara bersepadu dan memupuk amalan kitar semula melalui pedidikan di sekolah untuk mengatasi masalah ini. Program dan pengetahuan pelajar diharap dapat mengurangkan penjanaan komposisi sisa pepejal dan meningkatkan kebersihan kawasan sekolah dan alam sekitar.
\end{abstract}

Kata kunci: komposisi sisa pepejal, penjanaan, pelupusan, kitar semula

\section{Generation of Solid Waste Composition on Recycling Practices at Datuk Peter Mojuntin Secondary School, Penampang, Sabah.}


Nowadays, the number of high school students is increasing every year. This phenomenon has caused problems to the generation of uncontrolled solid waste composition and even pollute the environment. Generating a lot of solid waste composition is a problem that is complicated enough to solve. Therefore, a preliminary survey related to the generation of solid waste composition using recycling method was conducted at a secondary school in Penampang district. This study aims to identify the type and amount of garbage produced by all school residents within a month on the school day. Researchers have used survey design by applying a qualitative approach through unstructured interviews and observations participated in this study. The study population is form four students, cleaning workers and Penampang district council officers to measure and weigh the amount of garbage produced in a day and a week using electronic scales. Through calculations in the form of percentages and weight calculations in kilograms. The results clearly show that the most solid waste produced is food waste of $75.63 \mathrm{~kg}$, the second is $71.46 \mathrm{~kg}$ of plastic and the third is $61.35 \mathrm{~kg}$ of polystyrene from the total solid waste in a week. While $38 \%$ of the solid waste produced by all school people is non-recyclable goods and $34 \%$ is potential and recyclable materials but can not be sold to vendors. While as much as $28 \%$ of the solid waste generated consists of recyclable materials and can be sold to vendors. With the total composition of solid waste produced, the school can take recycling measures to reduce the amount of waste that will be generated and sent to landfills. Therefore, the school should hold various recycling programs in an integrated manner and cultivate recycling practices through education in schools to overcome this problem. Students' programs and knowledge are expected to reduce the generation of solid waste composition and improve the cleanliness of school grounds and the environment.

Key words: solid waste composition, generation, disposal, recycling

\section{Pengenalan}

Isu sisa pepejal boleh didengari di mana-mana sahaja di pelusuk dunia pada masa sekarang. Di mana adanya pelajar, di situlah sisa pepejal dihasilkan dan dibuang (Mapa, 2017). Memandangkan jumlah pelajar sekolah semakin bertambah, maka masalah pembuangan sisa pepejal juga secara langsung akan meningkat (Zaini et al., 2017). Masalah sisa pepejal telah hangat diperbincangkan pada peringkat global dan juga dalam negara. Keadaan sebegini telah biasa kelihatan di merata-rata tempat sama ada di taman perumahan, tepi jalan raya, kawasan sekolah, taman permainan kanak-kanak, laluan jalan raya dan sebagainya di seluruh kawasan di negara kita (Hasnah et al., 2012). Situasi ini semakin serius dan menyebabkan alam sekitar kita semakin kotor, berbau busuk dan kesan pencemaran bertambah seperti udara, sisa pepejal, air, laut dan sebagainya yang seterusnya akan menjejaskan kesihatan manusia dan kehidupan flora serta fauna yang ada di sekitarnya (Hanifah et al., 2017). Terdapat sebahagian besar pelajar suka membuang sisa pepejal di merata tempat walaupun terdapat tong sampah yang disediakan oleh pihak sekolah di lokasi yang ditetapkan. Adakah masalah ini timbul disebabkan oleh sikap dan nilai sedia ada dalam diri seseorang pelajar atau kurikulum pendidikan yang dirancang oleh Kementerian Pendidikan Malaysia (KPM) tidak dapat menyedarkan dan membudayakan amalan kitar semula di kalangan pelajar sekolah? Berdasarkan data daripada Journalist Covering Technological, Societal and Media Topics, tahap penguasaan dan pemahaman tentang pengurusan sisa pepejal melalui kitar semula di negara maju adalah sangat tinggi jika diandingkan dengan Malaysia. Peratus kitar semula di negaranegara barat seperti negara Belgium (71\%), Austria (67\%), Belanda (66\%) dan Jerman (60\%) adalah tinggi manakala Malaysia masih pada tahap yang rendah iaitu 5\% sahaja (Aslina dan Haliza, 2015).

Oleh itu, pendidikan berkaitan dengan amalan kitar semula telah diperkenalkan oleh KPM dalam kurikulum standard sekolah menengah baru pada tahun 2019 melalui Dokumen Standard Kurikulum dan Pentaksiran (DSKP) bagi mata pelajaran Geografi tingkatan tiga dan juga diterapkan dalam mata pelajaran yang lain seperti Sains, Pendidikan Moral, Pendidikan Sivik dan Kewarganegaraan di sekolah menengah (KPM, 2019). Topik pengurusan sisa pepejal dan kitar semula telah diterapkan secara terus dalam topik Geografi tingkatan tiga. Selain itu, satu pelan pembangunan pendidikan telah dibangunkan oleh KPM (2013-2025) untuk melahirkan modal insan melalui penerapan nilai-nilai alam sekitar dalam diri setiap pelajar. Tujuan utama pelan ini adalah melahirkan pelajar sekolah yang mencintai alam sekitar 
dan menyertai program amalan kitar semula. Diharapkan pelan jangka panjang ini dapat juga menyedarkan dan mengubah pemikiran pelajar dalam pengurusan sisa pepejal di sekolah. Seterusnya dapat memupuk amalan kitar semula dalam diri setiap pelajar di sekolah pada masa akan datang. Strategi pemerhatian peringkat dunia menjelaskan bahawa penjanaan komposisi sisa pepejal adalah merupakan pengukur terpenting untuk mengubah sikap dan tingkah laku pelajar sehingga dapat membentuk etika baik dalam mengurus kitar semula dan kebersihan kawasan sekolah (Ezanee, 2016 ; Molia et al., 2020).

Ramai pihak percaya hanya melalui pendidikan sahaja, pemikiran dan tindakan seseorang pelajar dapat diubah (Roslee et al., 2012). Oleh itu, sekolah ialah institusi yang paling sesuai untuk mendidik dan membentuk sikap terhadap amalan kitar semula dan kebersihan alam sekitar di kalangan generasi akan datang agar lebih prihatin terhadap kebersihan kawasan sekolah dan alam sekitar. Di sekolah rendah dan menengah, pendidikan alam sekitar dan kitar semula telah lama diterapkan dalam mata pelajaran tertentu. Pelajar diwajibkan mengambil mata pelajaran ini dalam peperiksaan penilaian tingkatan tiga. Pendidikan ini bertujuan untuk memberi pengetahuan dan kesedaran mengenai penjanaan sisa pepejal dan cara mengitar semula untuk memelihara serta memulihara alam sekitar. Di samping itu, pelajar juga dapat memahami integrasi pendidikan kitar semula dalam kurikulum pendidikan untuk membudayakan amalan kitar semula sejak mereka di sekolah rendah lagi. (Nurul Hidayah, 2012).

Diharapkan melalui kurikulum baru ini dapat menambahkan pengetahuan guru dan pelajar dalam membentuk dan memupuk sikap yang positif serta lebih bertanggungjawab. Mereka dapat melaksanakan pelbagai program kitar semula melalui pendidikan kitar semula di peringkat sekolah. Namun, ramai yang gagal menterjemahkan kesedaran ke dalam bentuk komitmen (Starke, 1990). Terdapat ramai pendidik iaitu guru sekolah mempunyai pengetahuan dan berprofesional akan menyampaikan ilmu tersebut kepada pelajar sekolah dengan pelbagai teknik pengajaran yang menarik (Ramayah et al., 2012). Ini kerana masih terdapat segelintir guru menggunakan teknik pengajaran yang lama dan kurang menarik minat pelajar untuk memahami pengajaran guru dalam kelas. Pelajar tidak dapat menguasai sepenuhnya pengajaran yang disampaikan oleh guru dalam kelas dan mereka juga tidak mendapatkan pengetahuan yang sama daripada kawan atau dalam multimedia yang lain. Selain itu, kurang kempen berkaitan dengan amalan kitar semula yang dijalankan oleh kerajaan ataupun sektor swasta di sepanjang tahun persekolahan pelajar di sekolah (Mohd Syami et al., 2015). Ini telah menyebabkan budaya dan amalan kitar semula tidak berjaya ditanam dalam sanubari diri pelajar. Jika segala kempen dan program amalan kitar semula dapat dilaksanakan dengan baik di sekolah, masalah penjanaan sisa pepejal yang banyak tidak kelihatan di merata-rata tempat di seluruh kawasan sekolah (Hanifah et al., 2017). Walau bagaimanapun, pihak kerajaan telah memberikan kontrak dan menyumbangkan kewangan kepada syarikat swasta untuk mengupah pekerja pembersih di sekolah. Pekerja pembersih diupah dan tugasnya adalah membantu membersihkan setiap sudut dalam kawasan sekolah. Setiap tahun kerajaan telah memperuntukkan sejumlah wang dalam perkara ini untuk membantu menyelesaikan masalah kebersihan di sekolah dan menjaga kepentingan alam sekitar (Shahril, 2007).

\section{Objektif Kajian}

1) Mengetahui penjanaan komposisi sisa pepejal yang dihasilkan oleh warga sekolah dalam sebulan di sekolah menengah Datuk Peter Mojuntin, Penampang.

2) Mengenal pasti pengetahuan pelajar terhadap amalan kitar semula di sekolah menengah Datuk Peter Mojunti, Penamapang.

\section{Sorotan Literatur}

Komposisi sisa bermaksud mengasingkan dan memasukkan sisa mengikut jenis dalam tong kitar semula yang berbeza. Pengasingan sisa pepejal di sekolah melibatkan proses mengasingkan sisa pepejal yang dihasilkan mengikut komposisi sisa pepejal seperti kertas, plastik, lain-lain (kaca, tin aluminium, bahan logam, sisa elektronik), sisa makanan, dan sisa lain yang kotor dan tercemar (JPSPN, 2017). Pelbagai amalan kitar semula dapat dilakukan di sesebuah sekolah dengan lebih berjaya apabila data komposisi 
sisa yang dibuang oleh pelajar sekolah dapat dikenalpasti (Tan et al., 2001). Komposisi sisa diertikan sebagai nisbah bahan yang dijumpai pada bahan buangan. Sebahagian bahan yang digunakan adalah daripada sumber semula jadi seperti plastik makanan dan minuman, kertas serta sebahagiannya lagi daripada polimer yang tidak dapat dihuraikan (Hasnah et al., 2012).

Kehadiran pelbagai jenis komposisi sisa buangan juga dipengaruhi oleh faktor luaran seperti kedudukan geografi, tahap sosioekonomi penduduk, sumber tenaga dan cuaca (Mapa, 2007). Komposisi sisa buangan dan jumlah penghasilannya adalah berbeza berdasarkan kepada punca industri bahan itu dihasilkan dan aktiviti yang dibuat oleh masyarakat tersebut seperti kawasan perumahan, perniagaan, industri, institusi pendidikan dan kawasan pasar (Hassan, 2002). Di kawasan sekolah, sisa pepejal yang biasa dijumpai adalah plastik pembungkus makanan, polisterina, botol mineral, kertas, buku latihan, alatulis, sisa makanan, tin aluminium dan sebagainya. Menjelang tahun 2020, penjanaan sisa pepejal yang terhasil di Malaysia dijangka meningkat sebanyak 15.6 juta tan daripada 9.0 juta tan pada tahun 2000 (Khairul et al., 2015). Jadual 1 menunjukkan penjanaan komposisi sisa pepejal yang dilupuskan di Malaysia dalam bentuk kiraan peratus bagi tahun 2017 dan 2018 mengikut negeri di bawah Akta 672 .

Jadual 1 : Penjanaan Komposisi Sisa Pepejal yang dilupuskan di Malaysia dalam Bentuk Peratus

\begin{tabular}{lcccccccc}
\hline Negeri & Tahun & $\begin{array}{c}\text { Sisa } \\
\text { Makanan }\end{array}$ & Plastik & $\begin{array}{c}\text { Kerta } \\
\text { S }\end{array}$ & Besi & Kaca & $\begin{array}{c}\text { Sisa } \\
\text { Kebun }\end{array}$ & Lain-lain \\
\hline Johor & 2017 & 53.7 & 76.0 & 18.8 & 2.2 & 3.0 & 17.2 & 4.7 \\
& 2018 & 161.8 & 139.7 & 65.0 & 9.9 & 15.1 & 74.0 & 3.7 \\
Kedah & 2017 & 80.9 & 48.6 & 9.7 & 1.6 & 3.1 & 12.2 & 3.8 \\
& 2018 & 112.7 & 60.2 & 20.3 & 3.6 & 4.9 & 22.4 & 1.9 \\
Negeri & 2017 & 64.2 & 43.5 & 22.7 & 2.8 & 3.7 & 8.2 & 1.1 \\
Sembilan & 2018 & 111.2 & 131.0 & 44.7 & 9.7 & 15.0 & 56.6 & 26.7 \\
Kuala & 2017 & 44.9 & 60.5 & 47.0 & 5.1 & 2.0 & 14.8 & 0.5 \\
Lumpur & 2018 & 75.9 & 41.9 & 22.1 & 5.7 & 4.9 & 8.8 & 1.1 \\
Pahang & 2017 & 60.8 & 51.0 & 39.3 & 4.6 & 2.0 & 20.0 & 2.0 \\
& 2018 & 187.9 & 238.8 & 80.6 & 23.1 & 24.0 & 12.8 & 44.8 \\
Melaka & 2017 & 38.0 & 22.2 & 9.6 & 1.7 & 0.7 & 5.0 & 0.7 \\
& 2018 & 37.6 & 28.8 & 5.3 & 1.9 & 2.1 & 0.9 & 0.1 \\
Perlis & 2017 & 24.0 & 30.7 & 14.0 & 2.0 & 3.3 & 2.0 & 1.5 \\
& 2018 & 23.9 & 26.0 & 6.7 & 1.6 & 2.0 & 4.4 & 0.6 \\
\hline
\end{tabular}

Sumber: Jabatan Pengurusan Sisa Pepejal Negara (JPSPN, 2019)

Berdasarkan laporan JPSPN (2019), setiap negeri di Semenanjung Malaysia menunjukkan peningkatan dalam penghasilan sisa pepejal yang dilupuskan di tapak pelupusan terutamanya bagi sisa makanan dan sisa plastik bagi tahun 2017 dan 2018. Keadaan ini menandakan bahawa jumlah sisa yang dihasilkan bertambah mengikut kadar pertambahan jumlah penduduk. Setiap negeri ini mempunyai nilai keluasan dan jumlah penduduk yang berbeza dan data ini telah dibuktikan oleh laporan dari Portal Dewan Bandaraya Kuala Lumpur (2020) sebanyak 16,650 tan pembuangan sisa makanan di negara kita pada setiap hari. Ini diikuti oleh sisa plastik iaitu sebanyak $24 \%$ dan sebagainya. Sisa urbanisasi domestik di Malaysia pada tahun 2005 dianggarkan mencecah kira-kira 7.34 juta tan pepejal domestik di seluruh negara dan jumlah ini dijangkakan meningkat 30,000 tan sehari menjelang tahun 2020. Secara keseluruhannya, jumlah sisa pepejal yang terhasil menunjukkan peningkatan yang drastik (Khairul et al., 2015). Peningkatan Komposisi sisa dipengaruhi oleh banyak faktor seperti pembangunan ekonomi, budaya, geografi, sumber tenaga dan iklim. Malaysia sebagai sebuah negara sedang membangun dan populasi semakin bertambah, penggunaan bahan bukan organik iaitu plastik, kertas dan bahan logam juga meningkat manakala bahan organik pula menurun. Keadan yang sama juga berlaku di kawasan sekoah dengan penambahan bilangan pelajar sekoah pada setiap tahun (Haidy, 2019).

Seterusnya jadual 2 di bawah menunjukkan komposisi sisa pepejal yang dikitar semula oleh penduduk di Malaysia yang terdiri daripada plastik, kertas, tin aluminium, kaca, besi dan lain-lain. Plastik merupakan bahan yang terbanyak dikitar semula kerana ia boleh digunakan semula dan jangka hayatnya adalah panjang jika penduduk biasa menggunakan kontena dan beg kitar semula. Peratus kitar semula 
semakin bertambah dari tahun 2014 hingga 2018 di mana ia telah mencapai $24.06 \%$. Situasi ini berlaku berkemungkinan ada sebahagian kecil penduduk menjalankan perniagaan kitar semula. Mereka membeli barang dan bahan yang boleh dikitar semula daripada penduduk tempatan dengan harga yang rendah dan memproses menjadi bahan kitar semula yang boleh dijual pada harga yang lebih tinggi kepada syarikat kitar semula.

Jadual 2: Komposisi Sisa Pepejal yang Dikitar Semula di Malaysia (Tan)

\begin{tabular}{ccccccccc}
\hline Tahun & Plastik & Kertas & Tin & Kaca & Besi & Lain-lain & Jumlah & \% Kitar semula \\
\hline 2014 & 375 & 408 & 227 & 26 & 392 & 101 & 1529 & 13.2 \\
2015 & 586 & 412 & 251 & 44 & 359 & 194 & 2048 & 15.7 \\
2016 & 999 & 613 & 90 & 184 & 146 & 167 & 2340 & 17.5 \\
2017 & 988 & 1588 & 213 & 1.8 & 37 & 3.1 & 2826 & 20.9 \\
2018 & 1563 & 1629 & 182 & 52 & 118 & 0.06 & 3362 & 24.06 \\
\hline
\end{tabular}

Sumber: Jabatan Pengurusan Sisa Pepejal Negara (2019)

Mengikut laporan SWCorp Malaysia pada tahun 2015, jumlah penjanaan sisa pepejal di Semenanjung Malaysia pada tahun 2005 iaitu sebanyak 17,000 tan sehari. Jumlah ini telah bertambah kepada 22,000 tan sehari pada tahun 2012 dan meningkatkan lagi kepada 30,000 hingga 33,000 tan sehari pada tahun 2013. Anggaran bagi tahun 2020 pula dijangkakan akan kekal mencecah 30,000 sehari dengan menyedari kepentingan kerajaan mewajibkan pengasingan sisa pepejal di rumah mulai 1 September sejak tahun 2015 berdasarkan peraturan mengikut Akta Pengurusan Sisa Pepejal dan Pembersihan Awam 2007 (Akta 672). Peraturan ini hanya berkuatkuasa di Kuala Lumpur, Putrajaya, Pahang, Johor, Melaka, Negeri Sembilan, Perlis, Kedah dan diharapkan ia dapat mendidik rakyat supaya mengamalkan kitar semula dengan lebih berkesan dan efektif di lokasi tersebut. Dengan semua laporan penjanaan komposisi sisa pepejal di seluruh Malaysia telah membuktikan bahawa ramai daripada kita masih belum mengamalkan amalan kitar semula di rumah.

Begitu juga situasi di sekolah, terdapat banyak jenis komposisi sisa dihasilkan oleh semua warga sekolah. Antaranya termasuklah pembungkus makanan dan minuman, kertas, tin aluminium, botol mineral, sisa makanan dan sebagainya yang boleh dilihat saban hari di dalam kawasan sekolah. Lori pemungut sampah dari Majlis Daerah Penampang (MDP) akan pergi memungut sampah tersebut setiap seminggu sekali iaitu pada malam hari Jumaat atau Sabtu pagi. Terdapat juga stor yang dibina khas oleh pihak sekolah untuk meletak semua sisa pepejal yang dikumpulkan di sekolah. Pengetahun tentang penjanaan komposisi sisa pepejal amat perlu diketahui untuk memastikan dan menentukan cara yang paling sesuai untuk mengurangkan jumlah sisa yang terdapat dalam kawasan sekolah (Tan et al., 2001). Pihak pentadbir sekolah perlu bekerjasama dengan semua warga sekolah dan pihak majlis daerah untuk samasama mengurangkan jumlah sampah yang dihasilkan dengan melakukan pengasingan sampah setelah mengetahui komposisi sisa pepejal yang dihasilkan. Ini bertujuan untuk mengurangkan jumlah sisa pepejal yang perlu dihantar ke tapak pelupusan. Jadi, jangka hayat tapak pelupusan boleh dipanjangkan pada masa akan datang (Abdul Hair, 2016).

Justeru itu, mengikut garis panduan sistem pengurusan sisa pepejal bagi pembangunan baru yang dikeluarkan oleh Perbadanan Pengurusan Sisa Pepejal dan Pembersihan awam (PPSPPA, 2018) pada tahun 2012, kuantiti anggaran penjanaan sisa pepejal seharian adalah bergantung kepada jenis kategori pembangunan yang dicadangkan contohnya bagi pejabat dianggarkan menghasilkan $0.15 \mathrm{~m}^{3}$ sisa pepejal bagi setiap $300 \mathrm{~m}^{2}$ dalam sehari manakala bagi sebuah sekolah pula dianggarkan menghasilkan sisa yang lebih banyak iaitu $0.003 \mathrm{~m}^{3}$ sisa pepejal bagi setiap pelajar dalam sehari. Ini bermaksud jika jumlah pelajar adalah seramai 1905 orang, jumlah sampah yang dihasilkan pada setiap hari dalam anggaran $5.715 \mathrm{~m}^{3}$. Cuba bayangkan jika sisa pepajal yang dihasilkan oleh para pelajar seramai seminggu, sebulan dan setahun. Angka ini memang amat mengejutkan dan membimbangkan pada zaman sekarang kerana ia akan mendatangkan masalah kebersihan dan mencemarkan alam sekitar serta ruang permukaan bumi.

Oleh hal yang demikian, Pihak Berkuasa Tempatan dan pelajar sekolah mula meneroka dan mengurus lebih lanjut mengenai amalan kitar semula bagi mengatasi masalah sisa pepejal sekolah. Menurut Saman Jafartayari (2010) semakin ramai pencinta alam sekitar tampil untuk melibatkan diri dalam amalan kitar 
semula tetapi masih tidak berjaya. Kenyataan ini disokong oleh Lane dan Wagner (2013) menjelaskan matlamat kitar semula adalah untuk mengurangkan jumlah kutipan dan sisa bahan kitar semula agar sisa tersebut tidak meningkat semasa pelupusan. Walaupun amalan kitar semula adalah satu langkah yang paling penting dan berkesan dalam meminimumkan sisa buangan tetapi kajian Norsilan (2006) adalah di sebaliknya. Kegagalan kempen amalan kitar semula adalah disebabkan oleh faktor dari segi tahap kesedaran, kekangan pentadbiran dan undang-undang negara kita. Kajian disokong oleh Mior Amran (2008) bagi menilai tahap kesedaran mengenai amalan kitar semula plastik yang dilakukan di pasar raya Jusco di Johor. Keputusan 54\% daripada jumlah responden kurang sedar adan kesedaran adalah pada tahap yang rendah. Wang (2006) yang menguji keberkesanan amalan kitar semula juga menunjukkan tahap kesedaran dan penglibatan semua penduduk Malaysia dalam amalan kitar semula tidak mampu memberi motivasi kepada orang awam khususnya pelajar sekolah untuk mengambil tindakan mengitar semula secara berkesan. Oleh itu, antara cara untuk mengurus dan meningkatkan jumlah bahan kitar semula adalah melalui penglibatan pelajar di sekolah dalam pelbagai program kitar semula.

Namun, kesedaran mengenai amalan kitar semula dalam kalangan pelajar masih lagi berada di tahap rendah berbanding negara maju yang lain (Ezanee et al., 2016). Kebanyakan masalah ini berpunca daripada perbuatan dan penglibatan pelajar yang kurang. Oleh itu, terdapat tiga elemen penting dalam membudayakan dan mengurus pelbagai amalan kitar semula iaitu melalui kurikulum pendidikan, penglibatan dan kesedaran pelajar. Amalan kitar semula ini sebagai petunjuk dan tanda bermulanya kempen kesedaran dan penglibatan terhadap kepentingan alam sekitar dan kebersihan di kawasan sekolah supaya jumlah sisa pepejal yang dihasilkan dapat dikurangkan sebelum dihantar ke tapak pelupusan sampah (Abdul Hair, 2016). Pada masa ini, penglibatan banyak dikaitkan dengan kesanggupan setiap individu untuk terlibat dalam aktiviti sokongan seperti kitar semula bahan seperti tin aluminium, kertas dan bahan lain yang mempunyai nilai untuk dikitar semula (Mapa, 2017). Walau bagaimana pun, kesediaan untuk melibatkan diri secara langsung memerlukan panduan dan dorongan dari pihak atasan contohnya di sekolah, perlu dapat sokongan penuh daripada pengetua, pentadbir, guru, pelajar dan semua kontraktor di sekolah. Oleh itu, setiap pelajar sekolah perlu bertanggungjawab terhadap amalan kitar semula di peringkat sekolah malah pengutipan sisa pepejal dari kelas ke kelas juga dilaksanakan sebelum pelajar dibenarkan pulang. Pengutipan kedua pula merupakan proses pengangkutan sisa pepejal ke tapak pelupusan dan ini dijalankan oleh MDP. Dalam hal ini, penglibatan pelajar sekolah juga boleh menjadi satu kaedah alternatif untuk meningkatkan tahap kebersihan terutama di kawasan persekolahan dengan menjadikan pelajar sebagai rakan penting dengan PBT (Tenku Afriza dan Abdul Rahman, 2013).

Ini dipersetujui oleh Masyitah et al., (2011) dalam kajian penjanaan sisa pepejal dan tahap kesedaran penduduk terhadap pengurusan kitar semula di negeri Perlis. Hanya sedikit iaitu 58\% daripada 1000 orang responden yang melibatkan diri dalam amalan kitar semula. Penduduk menyedari kitar semula tetapi kurang cenderung untuk menguruskannya disebabkan oleh beberapa faktor seperti tiada kemudahan pusat kitar semula dan tong sampah kitar semula tidak disediakan oleh pihak penganjur (Hanifah Mahat et al., 2017; Murugan, 2019). Oleh tu, motivasi kempen perlu dititikberatkan semasa mengurus kitar semula dan tong kitar semula secara percuma perlu dibekalkan untuk semua penghuni kediaman dan lokasi sekolah supaya aktiviti kitar semula ini berjaya dilaksanakan sepenuhnya di seluruh negeri di Malaysia. Kerajaan Malaysia telah membangunkan kurikulum kitar semula melalui guru di sekolah dan mengadakan pelbagai program dengan matlamat agar setiap pelajar memahami kepentingan untuk melindungi bumi melalui konsep 3R iaitu Reduce (Pengurangan), Reuse (Penggunaan Semula) dan Recycle (Kitar Semula). Ini kerana kitar semula melalui 3R merupakan salah satu cara utama untuk mengurus dan mengurangkan sisa pepejal yang ada di mana-mana tempat di seluruh negara kita (Hasnah et al., 2012).

\section{Metod Kajian}

Populasi kajian ini terdiri daripada semua pelajar sekolah menengah di sekolah Menengah Kebangsaan Datuk Peter Mojuntin, Penampang, Sabah. Daripada jumlah populasi ini, pengkaji telah memilih sampel iaitu pelajar tingkatan empat. Pelajar ini dipilih secara rawak mudah kerana mereka tidak terlibat dengan peperiksaan penting di sekolah dan mereka boleh membantu pengkaji dalam kajian ini. Responden seramai lima orang pelajar telah dipilih dari setiap kelas yang berjumlah 20 pelajar dalam kajian ini. 
Pengkaji menggunakan 20 orang pelajar ini untuk membantu mendapatkan data berkaitan dengan penjanaan komposisi sisa pepejal yang dihasilkan oleh pihak sekolah. Oleh itu, pengkaji telah menggunakan pemerhatian ikut serta dan temu bual separa berstruktur dalam kajian ini. Kaedah pemerhatian ikut serta merupakan salah satu pendekatan untuk mendapatkan data kualitatif. Menurut Othman Lebar (2014) , pemerhatian ikut serta dapat menunjukkan keadaan dan situasi yang tidak dapat dihuraikan oleh peserta kajian melalui kata-kata disebabkan oleh batasan seseorang individu itu. Melalui pemerhatian ikut serta, pengkaji dapat memperoleh data dengan cara menyertai kehidupan seharian pelajar dan pekerja pembersih yang dikaji.

Setiap tingkah laku pelajar boleh dijadikan sebagai maklumat dengan memerhatikan penglibatan pelajar terhadap setiap aktiviti amalan kitar semula dan penjanaan sisa pepejal di sekolah. Namun, tingkah laku pelajar akan berubah menjadi lakonan jika menyedari mereka diperhatikan. Oleh itu, pengkaji berusaha untuk mengelakkan pelajar yang dikaji daripada menyedari bahawa tingkah laku mereka sedang diperhatikan. Ini untuk membuktikan tingkah laku yang dilihat adalah realiti sebenar bukan lakonan semata-mata. Jadi, data yang diperoleh mempunyai kebolehpercayaan yang tinggi dan etika penyelidikan juga tidak dapat dipertikaikan. Selain itu, pengkaji juga memerhati cara bagaimana pekerja pembersih sekolah menimbang, mengikat, memungut dan menghantar sisa pepejal di sekolah sebelum dipungut oleh pegawai majlis daerah Penampang ke tapak pelupusan sampah. Di sini, para pelajar juga memainkan peranan membantu pihak berkuasa tempatan dan pihak sekolah dalam kerja-kerja penjanaan dan pengasingan sisa pepejal.

Sehubungan dengan itu, pemerhatian melalui analisis situasi juga digunakan untuk mengetahui amalan dan corak kitar semula di sekolah ini. Analisis situasi sangat penting untuk memberi input yang berguna kepada pengkaji untuk mengenal pasti permasalahan di kawasan kajian. Menurut Noraini Idris (2010), pendekatan analisis situasi dapat membantu pengkaji untuk melihat keadaan semasa di kawasan kajian sebelum menjalankan penyelidikan. Kajian lapangan dijalankan untuk memperoleh data berkaitan peratusan komposisi sisa pepejal yang boleh dikitar semula dan jumlah sampah yang dihasilkan setiap hari semasa hari persekolahan dalam masa seminggu. Alatan yang digunakan semasa kerja lapangan adalah penimbang elektronik mudah alih dengan kiraan dalam kilogram, plastik sampah, sarung tangan getah, buku $\log$ dan sebagainya. Peratusan komposisi sisa pepejal ini dapat menggambarkan permasalahan yang ada dalam amalan kitar semula di sekolah.

Seperti pendekatan kualitatif yang lain, temu bual berstruktur memerlukan penemubual menyediakan satu set soalan yang telah disediakan. Untuk mendapatkan data yang relevan melalui temu bual, penemu ramah perlu berfikiran terbuka, tidak bias dan bertanya soalan yang mempunyai makna (Othman Lebar, 2014). Temu bual juga boleh digunakan untuk menambahkan maklumat baru yang dapat meningkatkan lagi maklumat kajian. Individu yang ditemu bual adalah pelajar yang terlibat secara mendalam bagi penjanaan sisa pepejal dan amalan kitar semula. Selain itu, individu yang terlibat iaitu kontraktor dan pentadbir sekolah serta pegawai majlis daerah juga ditemu bual. Tujuan temu bual dibuat adalah untuk mendapatkan maklumat untuk menjawab persoalan dan objektif kajian. Beberapa perkara perlu diketahui iaitu penjanaan komposisi pepejal yang dihasilkan oleh sekolah dan penglibatan mereka dalam pelbagai amalan kitar semula. Temu bual dijalankan dalam purata satu atau setengah jam bagi setiap sesi. Temu bual difokuskan kepada lima bahagian iaitu temu bual bersama dengan pelajar, guru, pentadbir, kontraktor dan juga pegawai majlis daerah Penampang. Sebelum temu bual dijalankan, beberapa perkara telah dilakukan seperti menghantar surat rasmi, email dan melalui telefon sebagai pemberitahuan hasrat temu bual itu dijalankan (Noraini Idris, 2010).

Sepanjang temu bual berlangsung, catatan bertulis dilakukan dan rakaman turut dibuat bagi memastikan setiap data yang terkandung dalam perbualan dapat diperolehi dengan tepat dan baik. Manakala temu bual bersama dengan kontraktor dan pegawai PBT juga dilaksanakan. Temu ramah dijalankan kepada seorang kontraktor dan seorang pegawai PBT dalam kawasan sekolah yang bertugas di blok tertentu. Antara soalan yang dikemukakan dalam temu bual ini adalah berlatar belakangkan lokasi termasuk jenis sampah yang dihasilkan, komposisi sisa, cara kutipan dan pengangkutan dan sebagainya. Selain itu, pembuangan sampah dan penggunaan jenis warna tong sampah juga akan ditemu bual secara terperinci untuk memastikan pelajar ada mengamalkan kitar semula di sekolah atau sebaliknya. 


\section{Hasil Kajian dan Perbincangan}

Melalui pemerhatian ikut-serta dan temu bual yang diadakan dalam masa sebulan di sekolah, kajian mendapati komposisi sisa pepejal yang dihasilkan oleh semua warga sekolah adalah pelbagai dan banyak. Pengkaji juga telah memantau jumlah sisa buangan secara harian, mingguan dan bulanan untuk mengenal pasti jenis dan kuantiti komposisi sisa pepejal yang dihasilkan dengan bantuan pekerja kontraktor, para pentadbir dan pelajar sekolah serta pegawai Majlis Daerah Penampang (MDP). Kebanyakan penutup tong sampah telah diikat dengan tali yang bertujuan untuk mengelakkan daripada hilang atau dipermainkan oleh pelajar yang nakal di sekolah. Situasi ini telah berlaku sebelum ini dan pihak pentadbir telah mengambil langkah bijak untuk mengatasinya. Penyediaan tong sampah seumpama ini adalah bertujuan untuk memudahkan para pelajar dan warga sekolah membuang sampah dengan lebih selesa dan cepat di kawasan paling berhampiran dengan kedudukan mereka (Ezanee, 2016).

Penjanaan komposisi sisa pepejal di semua lokasi sekolah telah dikumpulkan di satu tempat pengumpulan khas di sekolah sebelum dipungut oleh lori pemungut sampah dari MDP. Sisa-sisa pepejal yang dipungut akan dihantar ke kawasan tapak pelupusan sisa pepejal yang terletak di Telipok. Kerjakerja pengumpulan dan penghantaran ke tapak pelupusan ini dilakukan seminggu sekali iaitu pada malam hari Jumaat ataupun Sabtu pagi mengikut jadual pemungutan kecuali sekolah ada program khas seperti ekspo lestari, hari sukan sekolah dan sebagainya. Pihak sekolah akan menghubungi pihak MDP untuk memungutnya pada hari kejadian untuk mengelakkan sampah penuh dan melimpah keluar ke merata tempat. Manakala pemungutan dan pemindahan sampah dari tong sampah berwarna hitam ke dalam plastik hitam dilakukan oleh pekerja yang dikontrakkan kepada Syarikat Alyssa Enterprise pada setiap hari persekolahan di sekolah. Kerja pemungutan dan pembersihan ini dilakukan oleh empat orang pekerja kontraktor sebanyak tiga kali sehari selepas rehat kerana masa rehat pelajar bagi setiap tingkatan adalah berbeza dan jumlah pelajar adalah seramai 1402 bagi Sekolah kajian ini.

Pengumpulan sisa pepejal ini mesti dilakukan oleh para pekerja pada setiap hari selepas waktu rehat untuk mengelakkan penimbunan sisa pepejal yang terlalu banyak sehingga menyebabkan sampah tumpah dan bertebangan di merata tempat akibat tiupan angin (Murugan, 2019). Jika tidak dipungut segera, maka sisa pepejal tersebut akan mengganggu pemandangan, bau yang kurang menyenangkan dan penyebaran penyakit kepada pelajar dan penduduk sekitar (Hanifah et al., 2017). Jika sampah tersebut bertakung air hujan akan menyebabkan pembiakan nyamuk aedes dan membawa penyakit denggi. Selain itu, pekerja akan membersih dan memungut sampah di lokasi masing-masing dan memastikan lokasi mereka sentiasa bersih dan tidak ada sebarang sampah di dalamnya. Mereka akan bertugas mengikut jadual yang ditetapkan oleh ketua kebersihan. Pengetua, pentadbir dan guru bertugas memantau dan memeriksa semua lokasi sekolah supaya ia sentiasa bersih di sepanjang masa persekolahan. Oleh itu, pelbagai kategori sampah telah dipungut dan boleh dilihat daripada pemerhatian dalam plastik sampah yang dikumpulkan oleh pekerja pada setiap hari persekolahan.

Kategori sisa pepejal yang dijana di sekolah ini boleh dibahagikan kepada lapan kategori utama iaitu polisterina, plastik, sisa makanan, kertas, bahan logam, alat tulis, kadbod, dan lain-lain. Kategori kertas merujuk kepada kertas putih yang dicetak, kertas campuran, surat khabar, majalah. Duajenis plastik telah dikenal pasti iaitu jenis PET (botol plastik), High Density Polyethylene (HDPE) bekas makanan dan plastik lain seperti plastik bag, pembalut plastik dan sebagainya. Bagi komposisi sisa alat tulis didapati adalah daripada bahan yang berasaskan kayu seperti pencil, bahan perhiasan kecil dan serpihan atau potongan warna kayu pelajar untuk mata pelajaran seni visual dan sebagainya (SWCorp, 2015). Manakala bagi komposisi kumpulan sisa lain-lain pula, bahannya adalah terdiri daripada produk-produk barangan selain daripada komposisi yang dinyatakan dalam huraian ini. Penganalisisan ini amat penting dan perlu untuk mengenal pasti komposisi setiap kategori sisa pepejal yang dihasilkan dan dilupuskan untuk mengetahui potensi dan amalan kitar semula di sekolah kajian.

Secara keseluruhannya, komposisi sisa pepejal yang dihasilkan oleh semua warga sekolah boleh dikategorikan kepada bahan yang boleh dikitar semula, bahan yang berpotensi untuk dikitar semula dan bahan yang tidak boleh dikitar semula. Bahan yang boleh dikitar semula adalah bahan yang diterima dan dibeli oleh vendor kitar semula. Kelas kedua merujuk kepada bahan yang boleh dikitar semula tetapi tidak diterima oleh vendor kitar semula atas sebab-sebab yang tertentu dan kelas ketiga pula merujuk 
kepada barangan atau bahan yang tidak boleh dikitar semula. Jadual 3 menunjukkan kategori sisa pepejal yang dijana pada bulan Ogos 2020 di sekolah kajian.

Jadual 3 : Kategori Sisa Pepejal yang Dijana di Sekolah Pada Bulan Ogos 2020

\begin{tabular}{|c|c|c|c|c|}
\hline \multicolumn{2}{|c|}{ Kategori sisa pepejal yang dijana di sekolah } & \multicolumn{3}{|c|}{$\begin{array}{c}\text { Berpotensi untuk kitar } \\
\text { semula } \\
\end{array}$} \\
\hline & & $\mathbf{1}$ & 2 & 3 \\
\hline Sisa makanan & Tulang ayam, kulit, sisa organik & & $\mathrm{X}$ & \\
\hline Plastik & Jenis PET/Lain-lain & & & $\mathrm{X}$ \\
\hline Logam & Tin aluminium & $\mathrm{X}$ & & \\
\hline Polisterina & Bahan pembungkus makanan di kantin & & $\mathrm{X}$ & $\mathrm{X}$ \\
\hline Kadbod & Pembungkus kotak, kotak kertas & $\mathrm{X}$ & & \\
\hline Alat Tulis & $\begin{array}{l}\text { pencil, bahan perhiasan kecil dan serpihan } \\
\text { atau potongan warna kayu }\end{array}$ & & & $\mathrm{X}$ \\
\hline Kertas & $\begin{array}{l}\text { kertas putih yang dicetak, kertas campuran, } \\
\text { surat khabar, majalah. }\end{array}$ & $\mathrm{X}$ & & \\
\hline Lain-lain & Tisu, mask dan selain dalam kategori di atas & & & $\mathrm{X}$ \\
\hline
\end{tabular}

$1=$ Sisa ya ng boleh dikitar semula dan boleh dijual kepada vendor

$2=$ Sisa yang boleh dikitar semula tetapi tidak boleh dijual kepada vendor

$3=$ Sisa yang tidak boleh dikitar semula

Rajah 1 : Peratusan Sisa Pepejal Mengikut Kategori pada Bulan Ogos 2020

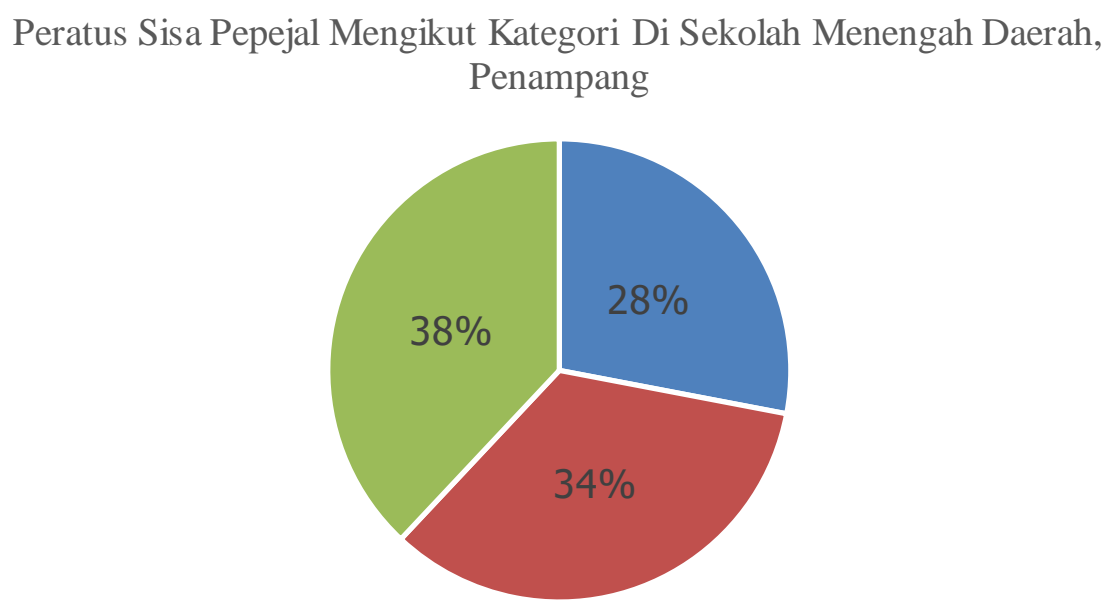

- Boleh dikitar semula dan boleh dijual kepada vendor

- Boleh dikitar semula tetapi tidak boleh dijual

- Tidak boleh dikitar semula

Merujuk kepada rajah 1, sisa pepejal yang dijana dan dilupuskan di sekolah terdiri daripada sisi pepejal yang boleh dikitar semula, berpotensi dikitar semula dan tidak boleh dikitar semula pada bulan Ogos 2020. Sisa pepejal yang dihasilkan ini adalah hampir sama jenis dan mempunyai peratus yang agak sama banyak kecuali cuti persekolahan seminggu atau hujung tahun. Sebanyak 38\% daripada sisa pepejal yang dihasilkan oleh semua warga sekolah merupakan barangan yang tidak boleh dikitar semula dan sebanyak $34 \%$ merupakan bahan yang berpotensi serta boleh dikitar semula tetapi tidak boleh dijual kepada vendor. Manakala sebanyak 28\% daripada sisa pepejal yang dijana terdiri daripada bahan yang boleh dikitar semula dan boleh dijual kepada vendor. Sisa pepejal yang boleh dikitar semula terdiri daripada sisa kertas, plastik, bahan logam iaitu tin aluminium dan kadbod. Manakala bahan yang berpotensi untuk dikitar semula merujuk kepada sebahagian sisa makanan dan polisterina. Seterusnya bahan yang tidak boleh dikitar semula merujuk kepada tisu, polisterina putih, beg plastik, pembalut plastik buku dan 
plastik yang lain yang mesti dilupuskan di tapak pelupusan. Hasil dapatan kajian Seow (2009) dan SWCorp (2015) juga menunjukkan majoriti daripada komposisi sisa pepejal yang dilupuskan berpotensi untuk dikitar semula.

Oleh itu, kajian telah mengenal pasti jenis dan kuantiti komposisi sisa pepejal yang dihasilkan oleh semua warga sekolah dalam masa sebulan di sekolah kajian. Jumlah sisa pepejal yang dihasilkan telah dikumpulkan dan diletakkan di tapak penyimpanan sisa pepejal dan akan ditimbang dengan menggunakan penimbang elektronik 10kg oleh pekerja kontraktor mengikut jenis komposisi sisa pepejal pada setiap hari persekolahan bagi bulan ogos 2020. Timbangan berat sisa pepejal bertujuan untuk mengetahui jumlah berat penghasilan sampah dalam masa sehari, seminggu dan sebulan. Manakala komposisi sisa pepejal bertujuan untuk mengenal pasti keberkesanan amalan kitar semula di sekolah dan adakah pengetahuan, penglibatan dan kesedaran di kalangan pelajar dapat mengubah amalan kitar semula di sekolah ini. Jadual 4 menunjukkan jumlah komposisi sisa pepejal dalam masa seminggu mengikut berat $(\mathrm{kg})$ yang dihasilkan oleh semua warga sekolah di Sekolah Menengah Kebangsaan Datuk Peter Mojuntin, Penampang.

Jadual 4 : Komposisi Sisa Pepejal Seminggu Mengikut Kilogram (KG)

\begin{tabular}{|c|c|c|c|c|c|c|}
\hline \multirow[t]{2}{*}{ Komposisi } & \multicolumn{6}{|c|}{ Jumlah Komposisi Sisa Pepejal Seminggu Mengikut KG di SMK DPM } \\
\hline & 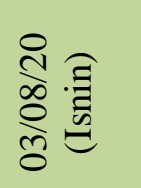 & 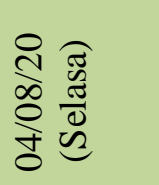 & 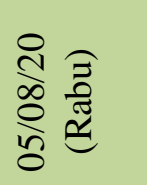 & 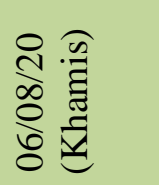 & 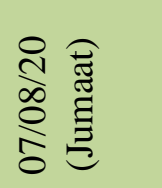 & 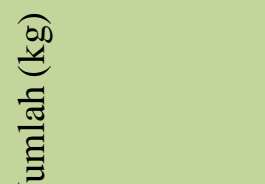 \\
\hline Sisa Makanan & 16.45 & 12.90 & 18.34 & 15.78 & 13.16 & 75.63 \\
\hline Plastik & 12.45 & 16.14 & 16.77 & 15.57 & 10.53 & 71.46 \\
\hline Polisterina & 10.53 & 12.90 & 12.50 & 12.26 & 13.16 & 61.35 \\
\hline Kertas & 10.53 & 6.45 & 8.45 & 9.64 & 5.23 & 40.30 \\
\hline Logam & 0.02 & 0.04 & 0.15 & 0.72 & 0.84 & 1.77 \\
\hline Alat Tulis & 0.12 & 0.15 & 0.18 & 1.24 & 1.10 & 2.79 \\
\hline Kadbod & 0.02 & 0.03 & 0.02 & 0.04 & 1.05 & 1.16 \\
\hline Lain-lain & 3.24 & 4.84 & 4.17 & 3.23 & 5.26 & 20.74 \\
\hline Jumlah & 53.36 & 54.45 & 60.58 & 58.48 & 49.33 & 275.20 \\
\hline
\end{tabular}

Jadual 4 menunjukkan komposisi sisa pepejal yang dihasilkan oleh semua warga sekolah dalam masa seminggu di sekolah kajian. Sisa makanan merupakan berat yang paling tinggi dijanakan oleh pelajar sekolah iaitu sebanyak $75.63 \mathrm{~kg}$ seminggu. Pecahan komposisi berat sisa makanan bagi seminggu persekolahan adalah di antara $12.90 \mathrm{~kg}$ hingga $18.34 \mathrm{~kg}$. Peratus kedua tertinggi adalah daripada komposisi plastik dengan jumlah sebanyak $71.46 \mathrm{~kg}$. Ia mempunyai berat masing-masing di antara 12.45 $\mathrm{kg}$ (Isnin), $16.14 \mathrm{~kg}$ (Selasa), $16.77 \mathrm{~kg}$ (Rabu), $15.57 \mathrm{~kg}$ (Khamis) dan $10.53 \mathrm{~kg}$ pada hari Jumaat. Manakala berat ketiga banyak adalah daripada bahan polisterina di mana beratnya berjumlah $61.35 \mathrm{~kg}$. Berat keempat banyak adalah kertas yang dihasilkan oleh para pelajar dan guru serta pentadbir sekolah iaitu seberat $40.30 \mathrm{~kg}$. Seterusnya lain-lain adalah seberat $20.74 \mathrm{~kg}$ dan bahan logam, alat tulis serta kadbod adalah sangat sedikit iaitu sebanyak satu hingga dua kilogram sahaja di sekolah ini. Penjanaan komposisi ini mempunyai kadar yang tidak tetap kecuali kadbod merupakan komposisi yang penjanaannya terendah dengan berat puratanya $1.16 \mathrm{~kg}$.

Jadual 5 : Jumlah Berat (KG) Komposisi Sisa Pepejal Sebulan di SMK DPM

\begin{tabular}{lccccc}
\hline Kategori Sisa & $\begin{array}{c}\text { Minggu 1 } \\
(\mathrm{KG})\end{array}$ & $\begin{array}{c}\text { Minggu 2 } \\
(\mathrm{KG})\end{array}$ & $\begin{array}{c}\text { Minggu 3 } \\
(\mathrm{KG})\end{array}$ & $\begin{array}{c}\text { Minggu 4 } \\
(\mathrm{KG})\end{array}$ & $\begin{array}{c}\text { Purata } \\
(\mathrm{KG})\end{array}$ \\
\hline
\end{tabular}


DOI: https://doi.org/10.47405/mjssh.v5i11.562

\begin{tabular}{lccccc}
\hline Sisa Makanan & 75.63 & 65.34 & 72.55 & 75.88 & 71.06 \\
Plastik & 71.46 & 60.34 & 58.12 & 53.19 & 59.71 \\
Polisterina & 61.35 & 65.34 & 58.16 & 60.58 & 61.36 \\
Kertas & 40.30 & 35.23 & 36.12 & 50.34 & 40.50 \\
Logam & 1.77 & 3.23 & 3.56 & 2.34 & 2.73 \\
Alat Tulis & 2.79 & 3.55 & 4.12 & 5.23 & 3.92 \\
Kadbod & 1.16 & 2.50 & 3.23 & 3.44 & 2.58 \\
Lain-lain & 20.74 & 24.78 & 28.47 & 25.38 & 24.84 \\
Jumlah & 275.20 & 260.31 & 234.33 & 276.38 & 266.70 \\
\hline
\end{tabular}

Jadual 5 menunjukkan komposisi sisa pepejal yang dihasilkan oleh semua warga sekolah menengah Datuk Peter Mojuntin dalam tempoh sebulan. Purata berat sebulan adalah sebanyak $266.70 \mathrm{~kg}$. Berat sampah yang terbanyak adalah sisa makanan iaitu seberat $71.06 \mathrm{~kg}$ manakala kedua banyak adalah polisterina dengan jumlah berat sebanyak $61.36 \mathrm{~kg}$. Seterusnya tangga ketiga adalah bahan plastik seberat $59.71 \mathrm{~kg}$ di mana kantin sekolah sendiri juga menggunakan plastik dan polisterina untuk membungkus makanan jualan mereka kepada para pelajar. Keempat adalah bahan kertas iaitu seberat $40.50 \mathrm{~kg}$ dan lain-lain bahan adalah seberat $24.84 \mathrm{~kg}$. Di samping itu, penggunaan bahan seperti logam, alat tulis dan kadbod adalah kurang daripada $5 \mathrm{~kg}$ yang masing-masing dengan kiraan berat sebanyak $2.73 \mathrm{~kg}, 3.92 \mathrm{~kg}$ dan $2.58 \mathrm{~kg}$ di sekolah tersebut.

Semua warga sekolah telah menjana komposisi sisa pepejal ke dalam tong sampah yang berwarna hitam atau hijau di setiap block bangunan di lokasi tertentu dalam kawasan sekolah. Jumlah keseluruhan tong sampah yang disediakan oleh pihak sekolah adalah berjumlah sebanyak 32 buah dan ia telah diletakkan di pelbagai lokasi dalam kawasan sekolah secara strategik. Jadual 6 menunjukkan bilangan tong sampah hitam yang berada di semua lokasi dalam kawasan sekolah. Nilai kadar penjanaan dalam setiap tong ini adalah tidak sama di mana ada tong sampah yang penuh dengan sampah dan ada yang separuh penuh dan ada yang sedikit. Pada kebiasaannya, tong sampah yang penuh dengan sampah kebanyakkannya terdapat di kawasan tepi kelas pelajar dan tong sampah yang berada di ruang kosong iaitu sekitar ruang dewan dan kantin sekolah. Manakala yang sedikit sampah pula terdapat di kawasan pondok yang jauh sedikit daripada ruang bangunan dan kelas pelajar.

Jadual 6 : Bilangan Tong Sampah Hitam Mengikut Lokasi di SMK DPM

\begin{tabular}{lc}
\hline \multicolumn{1}{c}{ Lokasi } & Bilangan Tong Sampah Hitam \\
\hline Block Bangunan Baru & 8 \\
Block Bangunan Lama & 14 \\
Ruang luar bangunan sekolah & 10 \\
\multicolumn{1}{c}{ Jumlah } & 32 \\
\hline
\end{tabular}

Penjanaan sisa makanan yang banyak di sesuatu lokasi dipengaruhi oleh kumpulan manusia yang berada atau mendiami kawasan tersebut. Menurut Mapa (2007) dan SWCorp (2015), Corak dan penjanaan komposisi sisa pepejal di sesebuah kawasan sangat dipengaruhi oleh jumlah pelajar dan fungsinya. Begitu juga situasinya di kawasan sekolah yang dipengaruhi oleh sisa daripada hasil makanan pelajar dan sisa bahan cetak sekolah. Selain itu, ia juga dipengaruhi oleh jumlah pelajar sekolah yang semakin bertambah yang menyebabkan penghasilan sisa pepejal yang semakin meningkat sehingga dihantar ke tapak pelupusan sampah (Abdul Hair, 2016). Oleh itu, sisa makanan dan plastik serta polisterina merupakan sisa pepejal yang terbanyak yang dihasilkan di sekolah kajian kerana fungsinya sebagai sekolah menengah dan pusat akademik pelajar. Menurut Leblanc (2017), polisterina merupakan bahan yang kekal berada dalam bentuk asal sehingga beratus-ratus tahun dan akan lupus sekitar 500 tahun (Zaini et al. 2017). Kenyataan ini juga disokong oleh Norpishah et al., (2017) bahawa bahan plastik ini tidak mudah dilupuskan kecuali ia dibakar dan akan membawa kesan buruk seperti pencemaran udara dan bau kepada kesihatan manusia dan alam sekitar. 
Memandangkan jumlah pelajar dan penghasilan sisa pepejal di sekolah semakin bertambah pada masa kini, pihak sekolah telah mengambil pendekatan menggalakkan amalan kitar semula di sekolah. Pendekatan kitar semula dengan mengasingkan bahan seperti beg plastik, kontena, botol mineral, kertas, tin aluminium dan sebagainya di kawasan sekolah (Hasnah et a., 2012). Penggunaan pendekatan amalan kitar semula di sekolah dapat mengurangkan jumlah penghasilan sisa pepejal kerana sisa telah diasingkan mengikut jenis dan kegunaannya. Justeru, amalan guna semula dalam kalangan pelajar sekolah dapat dikenalpasti dan senario sebenar amalan yang dilakukan oleh warga sekolah. Situasi ini boleh dilihat dari segi pengasingan sampah dalam tong kitar semula dan amalan kitar semula di sekolah ini. Walau bagaimanapun, amalan kitar semula ini boleh diperbaiki dan diperkasakan melalui usaha dan komitmen pihak sekolah dengan PBT serta pertubuhan yang berkaitan dari semasa ke semasa (Zaini et al., 2017). Akan tetapi, peranan yang dimainkan oleh setiap warga sekolah ini perlu ditekankan kerana perubahan yang kecil, akan menghasilkan impak yang cukup besar kepada amalan kitar semula dalam sekolah (Murugan. 2019).

Oleh sebab pelajar sekolah ini mempunyai pemikiran dan tahap amalan yang berbeza, maka amalan kitar semula perlu ditanam dan dipertingkatkan lagi agar seiring dengan amalan program kitar semula dan pengurusan sisa pepejal yang lebih giat dan sistematik di sekolah. Menurut Masyitah et al. (2011), penglibatan dan kesedaran pelajar sekolah perlu sejajar dengan amalan kitar semula bagi memastikan konsep ini benar-benar dipraktikkan dan mencapai objektifnya. Justeru, penemuan Murugan (2019) turut memperkuatkan lagi hujah bahawa amalan kitar semula di sekolah perlu dipraktikkan dan dijadikan sebagai gaya hidup dalam seharian diri pelajar iaitu bermula dari aspek pembelian, penggunaan, pembuangan hinggalah ke peringkat pelupusan. Ini bertujuan untuk memastikan pelaksanaan amalan kitar semula sekolah lebih baik dan terancang. Kenyataan ini juga turut disokong oleh Zaini et al. (2017) yang berjaya mengenal pasti amalan kitar semula sebagai satu budaya dalam kehidupan masing-masing sejak di bangku sekolah lagi. Dengan peratusan ini dapat menunjukkan pelajar sekolah mengetahui dan ada mengamalkan kitar semula di sekolah tetapi masih tidak mencapai tahap yang membanggakan. Walaupun amalan kitar semula masih berada pada tahap sederhana tetapi sekurang-kurangnya dapat melahirkan pelajar yang mengetahui cara pengurusan sisa pepejal yang lebih baik dan sistematik. Seterusnya dapat memastikan komposisi sisa pepejal yang dihasikan dan memupuk penglibatan serta kesedaran pelajar dalam pelbagai amalan kitar semula di sekolah ini pada masa akan datang. Tambahan pula, pengetahuan juga adalah medium penting dan menjadi keperluan asas kepada pemahaman terhadap amalan kitar semula, pelajar perlu diberikan pengetahuan dan mempraktikkan amalan yang tepat dan bersifat berterusan untuk mengatasi masalah sampah di sekolah.

Justeru, ciri-ciri menjaga kebersihan kelas dan kawasan sekolah pelajar perlu dipupuk oleh guru dan para pentadbir sekolah bagi mendorong pelajar melibatkan diri secara serius dalam setiap amalan kitar semula yang dianjurkan oleh pihak sekolah. Hal ini kerana setiap amalan kitar semula amat penting di mana dapat memupuk minat sejak kecil bagi tujuan menjaga kebersihan dan mendidik para pelajar betapa pentingnya amalan ini. Selain itu, dalam usaha meningkatkan kesedaran amalan kitar semula dalam kalangan pelajar sekolah, golongan dewasa dan pihak sekolah turut memainkan peranan yang sangat penting dalam usaha ini. Ibu bapa pelajar dan guru haruslah menjadi teladan dalam menambah pengetahuan amalan kitar semula dalam kalangan pelajar sejak pra sekolah atau sekolah rendah lagi di samping pendidikan juga diperoleh secara formal di sekolah. Untuk mencapai kejayaan dan amalan ini, pihak sekolah harus membuat perancangan dengan mengadakan pelbagai program kitar semula dengan menerapkan pendidikan kitar semula dalam kurikulum dan kokurikulum sekolah. Penerapan kurikulum kitar semula dalam mata pelajaran geografi adalah sangat penting untuk memberikan pengetahuan kepada pelajar tentang kepentingan dan faedah pengurusan sisa pepejal dan kitar semula di rumah dan di sekolah.

\section{Kesimpulan}

Pengurusan sisa pepejal di Malaysia telah menelan belanja yang cukup besar setiap tahun bermula dari proses pengumpulan sehingga kepada proses pelupusan sampah di tapak pelupusan. Masalah peningkatan jumlah sisa pepejal khususnya di sekolah dengan penambahan jumlah pelajar perlu ditangani secara bersama dan ia memerlukan alternatif baru untuk mengurangkan jumlah sampah 
tersebut. Jika sebelum ini, pihak berkuasa tempatan diberikan tanggungjawab untuk mengurus sisa pepejal tersebut namun kini ia turut menjadi tanggungjawab secara bersama antara semua manusia di bumi ini untuk mengurangkan jumlah sampah yang dijana. Kini, pihak sekolah melalui kurikulum pendidikan, amalan kitar semula dan penjanaan komposisi sisa pepejal untuk menyedarkan diri pelajar tentang kepentingan amalan kitar semula dalam kehidupan masing-masing dalam dunia sekarang. Kerjasama daripada semua pihak adalah sangat penting untuk menjayakan amalan kitar semula dalam kawasan sekolah. Ceramah, gotong-royong dan kempen kitar semula perlu diadakan di sepanjang tahun masa persekolahan dan bukan sekadar ada sahaja mengikut keperluan semasa. Selain itu, pengetahuan dan pendedahan tentang amalan kitar semula perlu diajar oleh guru secara mendalam di sekolah dan ibu bapa di rumah juga perlu mengamalkan kitar semula untuk membantu pelajar mengetahui pengasingan sampah mengikut warna tong sampah yang ada di negara kita. Kitar semula juga dapat menjimatkan kos dengan cara pengurangan kos penyelenggaraan dan pengurusan sampah yang terbuang. Diharapkan segala aktiviti dan program yang dilaksanakan dalam pengamalan kitar semula dapat menjimatkan sumber semula jadi yang semakin terhad seperti kayu untuk membuat kertas dan mengurangkan pemanasan global.

\section{Rujukan}

Abdul, Hair. B. A. (2016). Pengurusan Tapak Pelupusan Mapan Melalui Pendekatan Kitar Semula di Sabah. Fakulti Kemanusiaan, Seni dan Warisan, Universiti Malaysia Sabah.

Aslina, I., \& Haliza, A. R. (2015). Pengetahuan dan Amalan Pengurusan Sisa Pepejal dalam Kalangan Masyarakat di Taman Mesra dan Taman Bakti Kota Bharu, Kelantan. Geografia, 3(2): 14-27

Ezanee, M. E., Zakirah, O., Norlida, M., Mohd, N. M. N., Santhirasegaran, S. \& Nadarajan, R. (2016). Program kitar semula: Persepsi Masyarakat terhadap ReDMac. Sains Humanika, 8(4): 1-7.

Haidy Hendry Dusim. (2019). The Sustainability of Solid Waste Management from the Perspective of Policy: Towards a Sustainable Solid Waste Management in Kota Kinabalu. (Tesis Doktor Falsafah). Universiti Malaysia Sabah: Kota Kinabalu.

Hanifah, M., Mohmadisa, H., Yazid, S., Nasir, N. \& Safyidatina, B. N. (2017). Pengetahuan dan Amalan Hijau dalam Klangan Murid Sekolah Rendah. Jurnal Pendidikan Malaysia, 42(1), 41-49

Hasnah, A., Dody, D., Noraziah, A., Maznah, I. \& sarifah, Y. (2012). Masyarakat dan Amalan Pengurusan Sisa pepejal ke arah kelestarian komuniti: Kes isi rumah wanita di Bandar Baru Bangi, Malaysia. Masyarakat, ruang dana lam sekitar (MATRA). Journal of Society and Space, 8(6), 64 75.

Hassan M. N. (2002). Solid Waste Management in Malaysia: Can We Charter Future Strategies? Proceeding International Conference Environmental Management: Ten Years After, 8(5), 64-75.

Jabatan Pengurusan Sisa Pepejal. (2017). Kementerian Perumahan dan Kerajaan Tempatan. Dipetik dari https://jpspn.kpkt.gov.my/index.php/pages/view/218

Jabatan Pengurusan Sisa Pepejal Negara. (2019). Pengurusan Sisa Pepejal Negara. Dipetik dari https://jpspn.kpkt.gov.my/index.php/pages/view/127

Khairul Bariyah Abd Hamid, Mohd Armi Abu Samah, Mohd Yusoff Ishak. (2015). Analisis Penjanaan dan Komposisi Sisa Pepejal di Kafe Bangunan Pentadbiran: Kajian Kes. Solid Waste Solution Journal, 1, 1-16

Kementerian Pendidikan Malaysia. (2019). Kurikulum Geografi, Kuala Lumpur.

Kementerian Pendidikan Malaysia, Pelan pembangunan pendidikan (2013-2025).

Lane, G. W. S \& Wagner, T. P. (2013). Examining Recycling Container Attributes and Household Recycling Practices. Resources, Conservation and Recycling, 75, 32-40.

LeBlanc, R. (2017). How Long does It Take Garbage to Decompose? Dipetik dari https://www.thebalance.com/how-long-does-it-take-garbage-to-decompose-2878033.

Mapa.M., T. (2007). Sustainable Waste Management in Malaysia: A Case Study of Recycling in Kota Kinabalu, Sabah. (Tesis Doktor Falsafah). School of Environmental Sciences. University of East Anglia: Norwich, England.

Mapa, M., T. (2017). Pengurusan Sisa Pejal Mapan: Penelitian keatas Dewan Bandaraya Kota Kinabalu. Geografi.pp, 182-200.

Masyitah, M. N., Nurjuhanah, J. \& Juliana, M. (2011). Kajian Penjanaan Sisa Pepejal dan Tahap Kesedaran Penduduk Terhadap Kitar Semula di Seluruh Negeri Perlis. Jurnal Intelek. 6, 1. 
Mior, S. (2008). Kajian Keberkesanan Sisa Pejal dan Tahap Aktiviti Kitar Semula Di Skudai. Fakulti Kejuruteraan Awam, Universiti Teknologi Malaysia.

Mohd Syami, A. Nik, E. S. A., Nur Ameera, K. Noor Suraya, H. syarifah, N. O., Mohd Zin, M. \& Nor Helme, P. (2015). Persepsi pelajar politeknik Kota Bharu terhadap program kitar semula. Quality time prosiding seminar setiausaha dan pembangunan pengurusan kualiti politeknik Malaysia. 1:146-149.

Molia, S. D., Mapa. M. T. \& George, F. (2020). Persepsi Masyarakat Tempatan terhadap Penguruan ESisa oleh Syarikat Swasta di Bandaraya Kota Kinabalu, Sabah. Malaysian Journal of Social Sciences and Humanities (MJSSH), 5(9), 217-227.

Murugan Mini Ratamun. (2019). Pengetahuan dan Amalan Kitar Semula oleh Guru Pelatih Institut Pendidikan guru. Jurnal penyelidikan IPGK., 16: 1-16.

Noraini, Idris. (2010). Penyelidikan dalam Pendidikan. Kuala Lumpur: McGraw-Hill Malaysia Sdn. Bhd.

Norpishah, A., Rosnani, A. \& Rozimah, T. (2017). Kitar Semula Sisa Pepejal si Politeknik Sultan Salahuddin Abdul Aziz Shah. Advanced Journal and Vocational Education, 1(1), 161-167.

Norsilan, (2006). Kajian Kitar Semula Sisa Pepejal di Dalam Kampus UKM, Bangi: Permasalahan dan Keberkesanan Kitar Semula. (Tesis Sarjana). Universiti Kebangsaan Malaysia: Kuala Lumpur.

Nurul, Hidayah. L. A. (2012) Pendidikan Alam Sekitar Merentas Kurikulum di Sekolah Rendah: Satu Penilaian Awal. In International Environment and Health Conference, Pulau Pinang, 195-204.

Othman, Lebar. (2014). Penyelidikan Kualitatif. Universiti Pendidikan Sultan Idris, Tanjung Malim: Perak.

Perbadanan Pengurusan Sisa Pepejal dan Pembersihan Awam. (2018). Garis Panduan Sistem Pengurusan Sisa Pepejal bagi Pembangunan Baru.

Ramayah, T., Lee, J. W. \& Lim, S. (2012). Sustaining the Environment Through Recycling: An Empirical Study. Journal of Environment Management, 102(1), 141-147.

Roslee, T., Dg. Norizah, A. K., Soon, S., B., S. \& Muniandy, S. (2012). Pendidikan alam sekitar dan hubungannya dengan pengetahuan dan kesedaran alam sekitar dalam kalangan pelajar sekolah menengah bandar dan luar bandar di daerah Tawau, 131-152.

Saman Jafartayari. (2010). Awareness of Sustainable Manufacturing Practices in Malaysian Manufacturers. (Tesis Doctoral). Faculty of Mechanical Engineering: Universiti Teknologi Malaysia.

Starke, L. (1990). Signs of Hope: Working towards Our Common Future.

SWCorp News Bil. 4/2015 (2015). SWCorp Malaysia

SWCorp News Bil. 5/2015 (2015). SWCorp Malaysia

Tan, B. H., Jamaluddin, N. H., \& Abdul, A. B. (2001). Penjanaan, komposisi sampah sarap dan pengurusannya di Lembangan saliran Linggi, National Seminar Environmental Management, Universiti Kebangsaan Malaysia.

Teuku, A. (2012). Peranan Pihak Berkuasa Tempatan dan Penglibatan Komuniti Tempatan dalam Pengurusan Sisa Pepejal di Malaysia: Kajian Kes di Kota Bharu, Kelantan.

Wang, J. (2006). All in One: Do Single-Stream Curbside Recycling Program Increase Recycling Rate? Dipetik dari http://nature.berkeley.edu/:http//nature.berkeley.edu/classes/es196/projects/2006 final /wang.pdf. 8 May.

Zaini, S., Sofia, A. \& Mohd, F. S. (2017). Pengetahuan Komuniti dan Amalan Pengurusan Sisa Pepejal di Negeri Sembilan. Journal of Society and Space, 13(4), 126-137 